\title{
PERLAKUAN NAUNGAN DAN PEMBERIAN NaCl UNTUK MENGHAMBAT PERTUMBUHAN BATANG BAWAH KARET (HEVEA BRASILIENSIS MUELL ARG.)
}

\author{
Treatment of Shading and $\mathrm{NaCl}$ Application \\ to Inhibit Growth of Rubber Rootstock (Hevea brasiliensis Muell Arg.) \\ Lestari ADMOJO*, Mudita Oktorina NUGRAHANI, dan Nur Eko PRASETYO \\ Balai Penelitian Getas, Pusat Penelitian Karet \\ Jalan Pattimura KM 6 PO BOX 804, Salatiga 50702 Jawa Tengah \\ *Email : tariadmojo@gmail.com
}

Diterima : 17 April 2018 / Disetujui : 31 Mei 2018

\begin{abstract}
The problem of rubber seed storage could be overcomed by seedling storage where growth of seedling is inhibited through application of shading and $\mathrm{NaCl}$ treatment. The research aims to understand the effect of shading duration and $\mathrm{NaCl}$ application on rubber rootstock. Each treatment repeated 3 times with 30 seeds for each replication. Observation had been done to root growth, shoot height, stem diameter and plant height. The results showed that 0,5\% $\mathrm{NaCl}$ and 96\% shading treatment significantly inhibited growth of rubber rootstock shoot height up to $43 \%-60 \%$ and stem diameter up to $41 \%$ $65 \%$, but not for root length. The growth inhibition continued into seven months after transplanting, where the growth inhibition reached 13\% - 36\% for stem diameter and 20\% - 39\% for plant height. One month shading treatment showed the highest result for stem diameter reached $5.88 \mathrm{~mm}$ and budding success reached $50 \%$ at seven months after transplanting.
\end{abstract} $\begin{aligned} \text { Keywords: } & \text { Growth inhibition; } \mathrm{NaCl} \text {; } \\ & \text { rootstock; rubber seedling; } \\ & \text { shading }\end{aligned}$

\begin{abstract}
Abstrak
Masalah penyimpanan biji pada tanaman karet antara lain dapat diatasi dengan penyimpanan seedling dengan cara menghambat pertumbuhannya. Hambatan tersebut dapat dilakukan dengan aplikasi naungan dan pemberian $\mathrm{NaCl}$. Penelitian ini bertujuan untuk mengetahui pengaruh lama naungan dan pemberian $\mathrm{NaCl}$ pada
\end{abstract}

simpan seedling terhadap pertumbuhan batang bawah karet. Masing-masing perlakuan diulang tiga kali dengan tiga puluh bibit setiap ulangan. Pengamatan meliputi panjang akar, tinggi tunas, diameter batang dan tinggi tanaman, baik saat di rumah kaca maupun setelah pindah lapang. Hasil penelitian menunjukkan perlakuan naungan $96 \%$ dan penyemprotan $\mathrm{NaCl} 0,5 \%$ di bawah naungan nyata menghambat pertumbuhan tunas hingga $43-60 \%$ dan diameter batang hingga 41$63 \%$, namun tidak menghambat pemanjangan akar. Hambatan pertumbuhan berlanjut hingga tujuh bulan setelah pindah lapang, mencapai 13-36\% untuk diameter batang dan 20-39\% untuk tinggi tanaman. Perlakuan lama naungan satu bulan menunjukkan nilai tertinggi untuk diameter batang dan tingkat keberhasilan okulasi, yaitu $5,88 \mathrm{~mm}$ dan $50 \%$ pada umur tujuh bulan setelah pindah lapang.

Kata kunci : Batang bawah; hambatan pertumbuhan; $\mathrm{NaCl}$; naungan; seedling karet

\section{PENDAHULUAN}

Biji tanaman karet mengalami penurunan viabilitas yang cepat dalam beberapa hari, sehingga penyimpanan biji masih menjadi kendala utama saat ini. Penyimpanan semaian biji (seedling) menggunakan metode penghambatan pertumbuhan diharapkan mampu menjadi alternatif untuk mempertahankan ketersediaan batang bawah tanpa kehilangan kemampuan tumbuh setelah 
masa simpan. Metode penghambatan pertumbuhan pada prinsipnya adalah menekan pertumbuhan seedling selama masa penyimpanan dengan memanipulasi kondisi lingkungan tempat simpan atau pemberian zat penghambat pertumbuhan tertentu dengan tetap mempertahankan daya hidupnya (Krishnapillay et al., 1999). Salah satu cara untuk memanipulasi kondisi lingkungan adalah dengan penempatan seedling di bawah naungan. Tanaman karet termasuk tanaman yang membutuhkan intensitas cahaya penuh untuk pertumbuhannya, sehingga perlakuan naungan dapat menjadi faktor penghambat pertumbuhan. Selain penempatan di bawah naungan, aplikasi penyemprotan $\mathrm{NaCl}$ juga diharapkan mampu menekan pertumbuhan dalam penyimpanan.

Sodium chloride atau $\mathrm{NaCl}$ adalah zat yang memiliki tingkat osmotik yang tinggi, sehingga dapat berfungsi sebagai medium inhibitor dalam proses metabolisme tanaman. Penyimpanan seedling dengan aplikasi penyemprotan $\mathrm{NaCl}$ di bawah naungan berhasil dilakukan pada beberapa tanaman berkayu, seperti pada tanaman kayu bawang (Dysoxylum moliscimum) pada konsentrasi $\mathrm{NaCl} \quad 0,5 \%$ (Syamsuwida \& Aminah, 2011), tanaman Agathis loranthifolia pada konsentrasi $\mathrm{NaCl} 5 \%$ (Satjapradja, Setyaningsih, Syamsuwida, \& Rahmat, 2006), tanaman mimba (Azadirachta indica) (Syamsuwida, Aminah \& Ateng, 2010), dan tanaman Shorea selanica (Suminta, 2004). Mekanisme penyerapan tanaman terhadap larutan garam yang diberikan pada media serupa pada larutan garam yang disemprotkan ke arah daun dimana garam yang terlarut dalam air dapat masuk ke ruang interselular melalui lubang stomata. $\mathrm{NaCl}$ konsentrasi rendah dapat memicu stres garam pada tanaman sehingga diharapkan dapat menekan pertumbuhan tanaman, namun tidak sampai meracuni tanaman dan menyebabkan kematian.

Mekanisme hambatan pertumbuhan yang diakibatkan oleh $\mathrm{NaCl}$ dapat terjadi melalui: (1) Menurunkan potensial air, sehingga sel tanaman sulit menyerap air dari luar. (2) Stres $\mathrm{NaCl}$ menginduksi Reaktif Oksigen Spesi (ROS), yang memicu stres oksidatif sekunder, mengganggu homeostatis redoks selular dan merusak komponen sel dan strukturnya. (3) Stres garam memberi pengaruh negatif terhadap rekonstruksi dinding sel dan re-sintesis yang mengganggu pemanjangan dan pembelahan sel-sel akar (Bina \& Bostani, 2017).

Pada seedling jambu mete (Anacardium occidentale) mekanisme hambatan pertumbuhan akibat stres garam berhubungan dengan hambatan pengurangan cadangan makanan pada kotiledon. Mobilisasi lipid dihambat oleh $\mathrm{NaCl}$ akibat pengurangan aktivitas lipase saat awal kemunculan dan perkembangan seedling. Hal tersebut juga menghambat akumulasi pati pada kotiledon yang berhubungan dengan rendahnya aktivitas sintase pati yang menghambat aktivitas amilolitik dan fosforilase pati saat perkembangan seedling. Mobilisasi protein dihambat oleh $\mathrm{NaCl}$, yang teramati dengan adanya akumulasi asam amino dan hambatan aktivitas proteolitik pada seedling yang mengalami stres garam (Marques, de Freitas, Nara, Prisco \& Gomes-Filho, 2013).

Tujuan penelitian ini adalah untuk mengetahui pengaruh penyemprotan $\mathrm{NaCl}$ $0,5 \%$ dan lama naungan yang berbeda terhadap pertumbuhan akar, tinggi tunas dan diameter batang setelah perlakuan dan pertumbuhan lanjutannya setelah pindah lapang pada seedling tanaman karet.

\section{BAHAN DAN METODE}

Penelitian dilaksanakan di rumah kaca dan persemaian lapangan, Balai Penelitian Getas pada bulan Maret 2016 hingga Maret 2017. Bahan yang digunakan berupa kecambah klon PB 260 stadium jarum, larutan $\mathrm{NaCl} 0,5 \%$, fungisida Dythane M-45, pupuk NPK dan media serbuk gergaji lembab 100\%. Alat yang digunakan adalah akuarium dengan ukuran $40 \times 40 \times 60 \mathrm{~cm}$, roottrainer, lux meter, timbangan, alat okulasi, semprotan, gembor, gunting, ember, cangkul, meteran, dan jangka sorong.

\section{Perlakuan dalam Penelitian}

Penelitian terdiri dari dua faktor. Faktor pertama adalah perlakuan penyemprotan $\mathrm{NaCl} 0,5 \%$, dan faktor kedua 
adalah lama naungan. Penelitian terdiri dari 7 kombinasi perlakuan, meliputi :

$\mathrm{KO}$ : Kontrol (tanpa naungan dan tanpa $\mathrm{NaCl}$ )

$\mathrm{K} 1$ : Naungan $96 \%$ selama 1 bulan

K2 : Naungan $96 \%$ selama 2 bulan

K3 : Naungan 96\% selama 3 bulan

$\mathrm{P} 1$ : Penyemprotan $\mathrm{NaCl} 0,5 \%$ + naungan 96\% selama 1 bulan

P2 : Penyemprotan $\mathrm{NaCl} 0,5 \%$ + naungan 96\% selama 2 bulan

P3 : Penyemprotan $\mathrm{NaCl} 0,5 \%$ + naungan 96\% selama 3 bulan

Semaian biji stadium pancing sebanyak tiga puluh kecambah per ulangan perlakuan dipindahkan ke dalam media serbuk gergaji lembab (cukup basah) dengan ketebalan $\pm 45 \mathrm{~cm}$ di bawah intensitas naungan 96\%. Intensitas naungan 96\% dengan menempatkan perlakuan di dalam rumah kaca dengan penambahan paranet pada bagian atas dan samping. Intensitas cahaya selanjutnya diukur menggunakan lux meter, dan menunjukkan persentase intensitas cahaya masuk sebanyak 3,85\% (580-970 lux). Naungan 96\% dipilih karena diduga bisa berperan dalam menghambat pertumbuhan seedling secara signifikan. Kecambah stadium pancing ditanam dengan perlakuan jarak tanam rapat $( \pm 2 \mathrm{~cm})$. Penyemprotan dengan $\mathrm{NaCl}$ 0,5\% dilakukan pada rentang waktu satu minggu sekali.

Selanjutnya pada 1, 2 dan 3 bulan setelah perlakuan, masing-masing sebanyak 20 tanaman dipindah tanam di lahan persemaian untuk melihat pertumbuhan lanjutannya. Sebelum dipindah ke lapangan, seedling dipindah ke dalam roottrainer dengan media tanam menggunakan top soil dan cocopeat dengan perbandingan 2 : 1 , daun dipangkas setengahnya dan dibiarkan dalam roottrainer selama satu hari. Pemeliharaan di lapangan meliputi penyiraman, pemupukan dan pengendalian penyakit. Okulasi dilakukan setelah umur bibit mencapai 6-7 bulan di lapangan.

\section{Parameter Pengamatan dan Analisis Data}

Pengamatan terhadap tanaman di rumah kaca dilakukan dengan mengukur panjang akar, panjang tunas dan diameter batang. Panjang akar dihitung dari leher akar hingga ujung akar tunggang, sedangkan panjang tunas diamati dari pangkal tunas hingga titik tumbuh tunas. Diameter batang diukur pada ketinggian 5 cm dari leher akar.

Pengamatan terhadap tanaman setelah pindah lapang terdiri dari pertumbuhan tanaman, persentase tingkat kematian dan persentase tingkat keberhasilan okulasi. Pertumbuhan tanaman meliputi tinggi tanaman dan diameter batang yang diamati setiap bulan hingga bulan ketujuh. Tinggi tanaman diukur dari pangkal batang di atas permukaan tanah hingga titik tumbuh tunas, sedangkan diameter batang diukur pada ketinggian $5 \mathrm{~cm}$ di atas permukaan tanah. Okulasi dilakukan pada saat batang bawah berumur 6-7 bulan. Setelah okulasi dilakukan pengamatan tingkat keberhasilan okulasi di lapangan. Batang bawah persemaian lapangan digunakan sebagai tanaman kontrol.

Data yang diperoleh selanjutnya dianalisis menggunakan sidik ragam dari Rancangan Acak Lengkap (RAL) faktorial dua faktor dan uji lanjut menggunakan Uji Tukey untuk data yang berbeda nyata.

\section{HASIL DAN PEMBAHASAN}

\section{A. Panjang Akar, Tinggi Tunas dan Diameter Batang setelah Perlakuan}

Tabel 1 menunjukkan hasil sidik ragam pengaruh perlakuan pemberian $\mathrm{NaCl}$ dan lama naungan terhadap parameter pengamatan panjang akar, tinggi tunas dan diameter batang. Penyemprotan $\mathrm{NaCl}$ memberikan pengaruh yang sangat nyata terhadap peubah panjang akar, berpengaruh nyata terhadap peubah tinggi tunas dan tidak memberikan pengaruh yang nyata terhadap peubah diameter batang. Lama naungan memberikan pengaruh yang sangat nyata terhadap peubah panjang akar, tinggi tunas maupun diameter batang. Interaksi antara pemberian $\mathrm{NaCl}$ dan lama naungan memberikan pengaruh yang sangat nyata terhadap peubah panjang akar, namun pengaruhnya tidak nyata terhadap peubah tinggi tanaman dan diameter batang. 
Tabel 1. Rekapitulasi hasil sidik ragam pengaruh perlakuan terhadap peubah panjang akar, tinggi tunas, dan diameter batang seedling karet

Table 1. Analysis of variances summary for root length, shoot height, and stem diameter of rubber seedling

\begin{tabular}{cccc}
\hline $\begin{array}{c}\text { Perlakuan } \\
\text { Treatments }\end{array}$ & $\begin{array}{c}\text { Panjang akar } \\
\text { Root length } \\
(\mathrm{cm})\end{array}$ & $\begin{array}{c}\text { Tinggi tunas } \\
\text { Shoot height } \\
(\mathrm{cm})\end{array}$ & $\begin{array}{c}\text { Diameter batang } \\
\text { Stem diameter } \\
(\mathrm{mm})\end{array}$ \\
\hline $\mathrm{A}$ & $8,79^{* *}$ & $5,09^{*}$ & 2,54 \\
$\mathrm{~B}$ & $100,52^{* *}$ & $137,49^{* *}$ & $28,31^{* *}$ \\
$\mathrm{~A}^{* \mathrm{~B}}$ & $9,41^{* *}$ & 2,03 & 1,37 \\
\hline
\end{tabular}

Keterangan (Remarks) :
= nyata pada taraf $1 \%$ (significant at $1 \%$ level)
= nyata pada taraf $5 \%$ (significant at $5 \%$ level)
$\mathrm{A} \quad=$ penyemprotan $\mathrm{NaCl}$ di bawah naungan ( $\mathrm{NaCl}$ under shading treatment)
$\mathrm{B}=$ lama naungan (shading duration)
$\mathrm{A} * \mathrm{~B} \quad=$ interaksi antara penyemprotan $\mathrm{NaCl}$ di bawah naungan dan lama naungan
(interaction between NaClunder shading treatment and shading duration)

Hasil uji beda nyata dari peubah panjang akar, tinggi tunas dan diameter batang disajikan dalam Tabel 2. Rata-rata panjang akar menunjukkan hasil yang berbeda nyata antar perlakuan. Pada perlakuan naungan saja, perbedaan lama naungan tidak menunjukkan hasil yang berbeda nyata yaitu $20,15 \mathrm{~cm}$ pada lama naungan satu bulan, $17,60 \mathrm{~cm}$ pada lama naungan dua bulan dan $16,96 \mathrm{~cm}$ pada lama naungan tiga bulan. Panjang akar pada lama naungan satu bulan nyata lebih tinggi dibandingkan kontrol yang hanya mencapai $12,92 \mathrm{~cm}$, namun pada lama naungan tiga bulan, panjang akar nyata lebih rendah daripada kontrol yang mencapai $22,54 \mathrm{~cm}$. Pada perlakuan penyemprotan $\mathrm{NaCl}$ di bawah naungan, panjang akar menunjukkan nilai yang nyata lebih tinggi dibandingkan perlakuan lama naungan saja maupun kontrol. Berturut-turut yaitu 24,98 $\mathrm{cm}$ pada lama naungan satu bulan, 25,70 $\mathrm{cm}$ pada lama naungan dua bulan dan 29,50 $\mathrm{cm}$ pada lama naungan tiga bulan. Hasil tersebut menunjukkan bahwa penyemprotan $\mathrm{NaCl}$ di bawah naungan hingga tiga bulan tidak menghambat pemanjangan akar seedling karet.

Pada beberapa tanaman, pengaruh dari keracunan $\mathrm{NaCl}$ akan berdampak pada pengurangan panjang akar. Hal ini disebabkan sel-sel meristem akar sensitif terhadap mineral garam di mana pembelahan sel secara mitosis berlangsung sangat tinggi dalam pertumbuhan akar (Kusumiyati, Onggo \& Habibah, 2017). Pada penelitian ini menunjukkan hasil yang sebaliknya, dimana perlakuan $\mathrm{NaCl}$ di bawah naungan menunjukkan panjang akar yang lebih tinggi dibandingkan kontrol. Hal ini diduga konsentrasi $\mathrm{NaCl}$ belum cukup efektif untuk menghambat pemanjangan akar, disamping naungan dapat memberi pengaruh yang positif terhadap pemanjangan akar. Pacholczak dan Szydlo (2010) dalam Pey (2012) juga membuktikan bahwa naungan memberikan pengaruh yang positif pada perakaran Cornus alba L. Stres garam juga mampu memicu pemanjangan akar tunggang pada simpan seedling kayu bawang (Hendromono, 2001). Pengaruh $\mathrm{NaCl}$ dapat menurunkan kadar air di dalam tanaman, sehingga akar merespon dengan memperluas daerah penyerapan air dengan cara memanjangkan sel-sel epidermis (Muzzayyanah, 2017). Selain konsentrasi $\mathrm{NaCl}$, faktor lain mungkin berpengaruh yang menyebabkan hambatan pemanjangan akar tidak terjadi. Wahid et al. (1999) dalam Marques et al. (2013) menyatakan bahwa intensitas pengaruh stres garam terhadap hambatan pertumbuhan seedling tergantung beberapa faktor, yaitu asal biji (vigor, bentuk dan morfologi testa), kadar garam (konsentrasi dan waktu pelepasan) dan kondisi lingkungan sekitar biji (suhu, intensitas cahaya, kadar oksigen dan kelembaban). 
Tabel 2. Rata-rata panjang akar, tinggi tunas dan diameter batang pada setiap perlakuan Table 2. Average of root length, shoot height and stem diameter on each treatments

\begin{tabular}{ccccc}
\hline Umur & $\begin{array}{c}\text { Rata-rata } \\
\text { (bulan) }\end{array}$ & $\begin{array}{c}\text { Rata-rata } \\
\text { panjang akar } \\
\text { tinggi tunas }\end{array}$ & $\begin{array}{c}\text { Rata-rata } \\
\text { diameter batang }\end{array}$ \\
Treatments & $\begin{array}{c}\text { Age } \\
\text { (months) }\end{array}$ & $\begin{array}{c}\text { Average } \\
\text { of root length } \\
(\mathrm{cm})\end{array}$ & $\begin{array}{c}\text { Average of } \\
\text { shoot height } \\
(\mathrm{cm})\end{array}$ & $\begin{array}{c}\text { Average of } \\
\text { stem diameter } \\
(\mathrm{mm})\end{array}$ \\
\hline \multirow{2}{*}{ Naungan } & 1 & $20,15^{\mathrm{b}}$ & $9,11^{\mathrm{b}}$ & $1,98^{\mathrm{ab}}$ \\
& 2 & $17,60^{\mathrm{b}}$ & $8,28^{\mathrm{b}}$ & $1,35^{\mathrm{c}}$ \\
& 3 & $16,96^{\mathrm{b}}$ & $11,77^{\mathrm{b}}$ & $2,24^{\mathrm{a}}$ \\
& 1 & $24,98^{\mathrm{a}}$ & $10,10^{\mathrm{b}}$ & $1,79^{\mathrm{ab}}$ \\
& 2 & $25,70^{\mathrm{a}}$ & $12,25^{\mathrm{ab}}$ & $1,54^{\mathrm{c}}$ \\
& 3 & $29,50^{\mathrm{bc}}$ & $15,30^{\mathrm{a}}$ & $2,19^{\mathrm{a}}$ \\
& 1 & $12,92^{\mathrm{c}}$ & $19,69^{\mathrm{ac}}$ & $3,36^{\mathrm{b}}$ \\
& 2 & $20,03^{\mathrm{b}}$ & $21,23^{\mathrm{ac}}$ & $3,67^{\mathrm{b}}$ \\
\hline
\end{tabular}

Keterangan : Angka yang diikuti dengan huruf yang sama pada kolom yang sama menunjukkan tidak berbeda nyata pada taraf signifikasi $5 \%$.

Remaks : Figures followed by the same letter at the same column were not significantly different at $5 \%$.

Rata-rata tinggi tunas diantara perlakuan menunjukkan hasil yang berbeda, dan masih nyata lebih rendah dibandingkan kontrol. Hambatan tinggi tunas pada perlakuan lama naungan satu bulan mencapai 54\% $(9,11 \mathrm{~cm})$, lama naungan dua bulan mencapai $61 \%(8,28 \mathrm{~cm})$ dan lama naungan tiga bulan mencapai $60 \%$ $(11,77 \mathrm{~cm})$. Pada perlakuan penyemprotan $\mathrm{NaCl}$ di bawah naungan juga mengalami hambatan pertumbuhan tunas, dimana rata-rata persentase hambatan lebih rendah dibandingkan perlakuan lama naungan saja. Hasilnya berturut-turut adalah 49\% pada lama naungan satu bulan $(10,10 \mathrm{~cm})$, $43 \%$ pada lama naungan dua bulan $(12,25$ $\mathrm{cm}$ ) dan $48 \%$ pada lama naungan tiga bulan $(15,30 \mathrm{~cm})$. Hasil tersebut menunjukkan bahwa lama naungan dan penyemprotan $\mathrm{NaCl}$ sangat menekan pertumbuhan tunas seedling karet. Hasil tersebut sejalan pada tanaman Agathis loranthifolia, dimana perlakuan naungan lebih menekan pertumbuhan tinggi tanaman dibandingkan perlakuan $\mathrm{NaCl}$ saja (Satjapradja et al., 2006). Perlakuan naungan berat (lebih dari $75 \%$ juga menghambat pertumbuhan tunas pada tanaman Shorea selanica, mencapai 59\% lebih rendah dibandingkan kontrol tanpa naungan (Panjaitan, Wahyuningtyas, \& Ambarwati, 2011).
Hasil tersebut juga menunjukkan bahwa perlakuan naungan dan penyemprotan $\mathrm{NaCl}$ lebih menghambat tinggi tunas dibandingkan dengan panjang akar. Perlakuan $\mathrm{NaCl} 40$ dS·m-1 juga terbukti lebih berpengaruh terhadap panjang batang dibandingkan panjang akar pada tanaman cengkeh (Caryophyllus aromaticus L.) dan isabgol (Plantago ovata L.) (Bina \& Bostani, 2017). Tanaman C. innophyllum yang disemaikan pada intensitas cahaya 650 lux, proses fotosintesis masih dapat berlangsung namun tidak maksimal sehingga menyebabkan hambatan pertumbuhan tinggi tanaman (Aminah \& Syamsuwida, 2010). Selain naungan, cekaman salinitas juga dapat menyebabkan terhambatnya proses fotosintesis sehingga dapat menghambat pertumbuhan tanaman (Chaves, Flexas, \& Pinheiro, 2009). Hambatan tinggi tanaman kemungkinan juga berhubungan dengan pengaruh $\mathrm{NaCl}$ terhadap sintesis giberelin. Menurut Hawley (1981), $\mathrm{NaCl}$ tersusun dari $\mathrm{Na}+$ dan $\mathrm{Cl}-$ yang mana ion $\mathrm{Cl}$ nya secara analogis mempunyai sifat mekanisme yang sama dengan ion $\mathrm{Cl}$ yang terdapat dalam paklobutrazol, karena $\mathrm{Cl}$ merupakan elektrolit kuat sehingga dapat menimbulkan stres pada biosintesa giberelin. Giberelin merupakan hormon yang salah satunya berperan dalam pertumbuhan tanaman. 
Rata-rata diameter batang menunjukkan hasil yang nyata lebih rendah dibandingkan dengan kontrol. Diameter batang menunjukkan pola yang sama antara perlakuan naungan dan penyemprotan $\mathrm{NaCl}$ di bawah naungan, dimana nilai keduanya tidak berbeda nyata. Hambatan tersebut pada perlakuan lama naungan satu bulan mencapai $41 \%(1,98 \mathrm{~mm})$, lama naungan dua bulan mencapai $63 \%(1,35 \mathrm{~mm})$ dan lama naungan tiga bulan mencapai $41 \%$ $(2,24 \mathrm{~mm})$. Hambatan diameter batang pada perlakuan $\mathrm{NaCl}$ mencapai $47 \%$ (1,79 $\mathrm{mm})$ pada lama naungan satu bulan, 58\% (1,54 $\mathrm{mm}$ ) pada lama naungan dua bulan dan $43 \%$ pada lama naungan tiga bulan $(2,19 \mathrm{~mm})$. Hasil tersebut menunjukkan bahwa perlakuan naungan dan penyemprotan $\mathrm{NaCl}$ nyata menekan pertumbuhan diameter batang seedling karet. Seedling pada tanaman kayu bawang juga menunjukkan hasil senada, bahwa perlakuan zat penghambat tumbuh pada umur simpan yang lebih lama menghasilkan nilai pertambahan diameter batang yang kecil (Syamsuwida \& Aminah, 2011). Naungan berat juga mampu menekan pertumbuhan tinggi, diameter, berat kering pucuk dan berat kering akar pada tanaman Shorea assamica (Irawan \& Darwo, 2017). Terhambatnya pertumbuhan diameter batang disebabkan hasil fotosintesis dan spektrum cahaya matahari kurang merangsang aktivitas hormon dalam proses pembentukan sel meristematik ke arah diameter batang, terutama pada intensitas cahaya rendah (Daniel, Helms \& Baker, 1997). Gambar 1 menunjukkan perbedaan perakaran seedling karet setelah perlakuan.
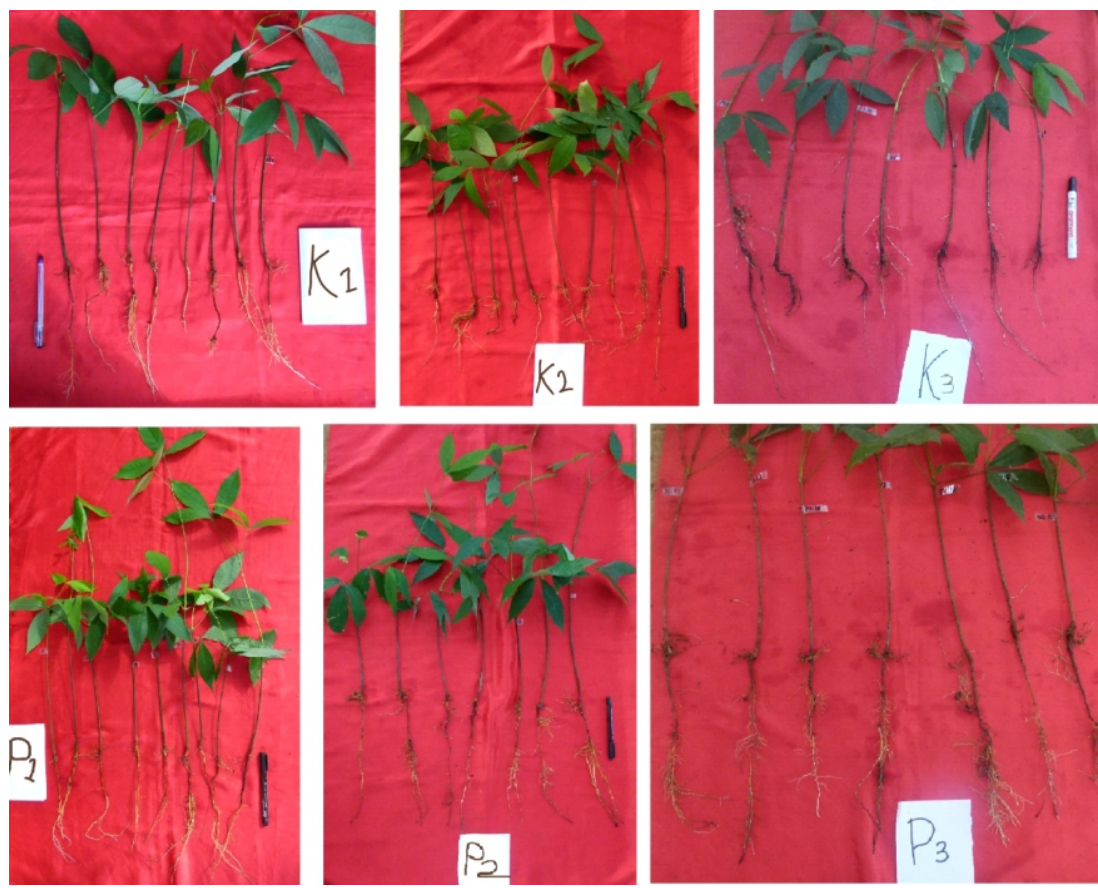

Keterangan (remarks):

K1 : Naungan 96\% selama 1 bulan (One month of $96 \%$ shading)

K2 : Naungan $96 \%$ selama 2 bulan (Two months of $96 \%$ shading)

K3 : Naungan $96 \%$ selama 3 bulan (Three months of $96 \%$ shading)

P1 : Penyemprotan $\mathrm{NaCl}$ 0,5\% + naungan 96\% selama 1 bulan $\mathrm{NaCl} 0.5 \%$ under one month of $96 \%$ shading)

P2 : Penyemprotan $\mathrm{NaCl} 0,5 \%$ + naungan $96 \%$ selama 2 bulan $(\mathrm{NaCl} 0.5 \%$ under two months of $96 \%$ shading)

P3 : Penyemprotan $\mathrm{NaCl}$ 0,5\% + naungan $96 \%$ selama 3 bulan $(\mathrm{NaCl} 0.5 \%$ under three months of $96 \%$ shading)

Gambar 1. Panjang akar dan tinggi tunas setelah perlakuan

Figure 1. Root length and shoot height after treatments 


\section{B. Diameter Batang dan Tinggi Tanaman Setelah Pindah Lapang}

Tabel 3 menunjukkan hasil sidik ragam pengaruh perlakuan pemberian $\mathrm{NaCl}$ dan lama naungan terhadap parameter diameter batang dan tinggi tanaman pada umur enam dan tujuh bulan setelah pindah lapang. Data bulan keenam dan ketujuh ditampilkan sebagai perbandingan usia batang bawah umumnya siap diokulasi. Perlakuan penyemprotan $\mathrm{NaCl}$ maupun interaksinya dengan lama naungan sangat nyata berpengaruh pada peubah diameter batang baik pada umur enam maupun tujuh bulan setelah pindah lapang. Pada peubah tinggi tanaman umur enam dan tujuh bulan setelah pindah lapang, penyemprotan $\mathrm{NaCl}$ dan interaksinya dengan lama naungan berpengaruh nyata, sedangkan lama naungan tidak memberikan pengaruh yang nyata.

Hasil uji beda nyata dari peubah diameter batang dan tinggi tanaman pada umur enam dan tujuh bulan setelah pindah lapang disajikan dalam Tabel 4. Seluruh perlakuan menunjukkan hasil yang nyata lebih rendah dibandingkan kontrol, baik pada peubah diameter batang maupun tinggi tanaman. Perlakuan lama naungan satu bulan menunjukkan hambatan diameter batang mencapai $13 \%(5,88 \mathrm{~mm})$, lama naungan dua bulan mencapai $22 \%$ $(5,27 \mathrm{~mm})$ dan lama naungan tiga bulan mencapai $23 \%(4,93)$ pada umur tujuh bulan setelah pindah lapang dibandingkan dengan kontrol. Hambatan tinggi tanaman pada perlakuan lama naungan satu bulan mencapai $25 \%(43,17 \mathrm{~cm})$, lama naungan dua bulan mencapai $31 \%(39,57 \mathrm{~cm})$ dan lama naungan tiga bulan mencapai 39\% $(35,02 \mathrm{~cm})$. Perlakuan $\mathrm{NaCl}$ di bawah naungan menunjukkan nilai rata-rata yang nyata lebih rendah untuk peubah diameter batang, dan nyata lebih tinggi untuk peubah tinggi tanaman dibandingkan perlakuan lama naungan saja pada umur tujuh bulan setelah pindah lapang. Hambatan diameter batang untuk perlakuan $\mathrm{NaCl}$ dengan lama naungan satu bulan mencapai 23\% (5,25 $\mathrm{mm})$, lama naungan dua bulan mencapai $36 \%(4,34 \mathrm{~mm})$ dan lama naungan tiga bulan mencapai 35\% (4,42 $\mathrm{mm})$ pada umur tujuh bulan setelah pindah lapang dibandingkan dengan kontrol. Hambatan tinggi tanaman pada perlakuan $\mathrm{NaCl}$ dengan lama naungan satu bulan mencapai $24 \%(44,11 \mathrm{~cm})$, lama naungan dua bulan mencapai $20 \%(46,23$ $\mathrm{cm})$ dan lama naungan tiga bulan mencapai $34 \%(38,06 \mathrm{~cm})$.

Tabel 3. Rekapitulasi hasil sidik ragam pengaruh perlakuan terhadap diameter batang dan tinggi tanaman pada umur enam dan tujuh bulan setelah pindah lapang.

Table 3. Analysis of variances summary for stem diameter and plant height at sixth and seventh months after transplanting

\begin{tabular}{ccccc}
\hline & Diameter batang & Diameter batang & Tinggi tanaman & Tinggi tanaman \\
bulan 6 & bulan 7 & bulan 6 & bulan 7 \\
Perlakuan & Stem diameter & Stem diameter & Plant height & Plant height \\
Treatments & 6 months old & 7 months old & 6 months old & 7 months old \\
& $(\mathrm{mm})$ & $(\mathrm{mm})$ & $(\mathrm{cm})$ & $(\mathrm{cm})$ \\
\hline $\mathrm{A}$ & $9,24^{* *}$ & $10,66^{* *}$ & $3,71^{*}$ & $4,09^{*}$ \\
$\mathrm{~B}$ & 0,59 & 0,75 & 0,55 & 0,51 \\
$\mathrm{~A}^{*} \mathrm{~B}$ & $4,05^{* *}$ & $4,71^{* *}$ & $1,82^{*}$ & $1,94^{*}$ \\
\hline
\end{tabular}

Keterangan (Remarks) :

$=$ nyata pada taraf $1 \%$ (significant at $1 \%$ level)

= nyata pada taraf $5 \%$ (significant at $5 \%$ level)

$\mathrm{A}=$ penyemprotan $\mathrm{NaCl}$ dibawah naungan ( $\mathrm{NaCl}$ under shading treatment)

$\mathrm{B}=$ lama naungan (shading duration)

$\mathrm{A} * \mathrm{~B}=$ interaksi antara penyemprotan $\mathrm{NaCl}$ dibawah naungan dan lama naungan (interaction between $\mathrm{NaCl}$ under shading treatment and shading duration) 
Tabel 4. Rata-rata diameter batang dan tinggi tunas pada umur 6 dan 7 bulan setelah pindah lapang

Table 4. Average of stem diameter and shoot height at 6 and 7 months after transplanting

\begin{tabular}{|c|c|c|c|c|c|}
\hline \multirow{2}{*}{$\begin{array}{l}\text { Perlakuan } \\
\text { Treatments }\end{array}$} & $\begin{array}{l}\text { Lama naungan } \\
\text { (bulan) }\end{array}$ & $\begin{array}{c}\text { Diameter batang } \\
\text { bulan } 6\end{array}$ & $\begin{array}{c}\text { Diameter batang } \\
\text { bulan } 7\end{array}$ & $\begin{array}{l}\text { Tinggi tanaman } \\
\text { bulan } 6\end{array}$ & $\begin{array}{l}\text { Tinggi tanaman } \\
\text { bulan } 7\end{array}$ \\
\hline & $\begin{array}{c}\text { Shading Duration } \\
\text { (months) }\end{array}$ & $\begin{array}{l}\text { Stem diameter } \\
6 \text { month old } \\
(\mathrm{mm})\end{array}$ & $\begin{array}{l}\text { Stem diameter } \\
7 \text { month old } \\
(\mathrm{mm})\end{array}$ & $\begin{array}{l}\text { Plant height } \\
6 \text { month old } \\
(\mathrm{cm})\end{array}$ & $\begin{array}{l}\text { Plant height } \\
7 \text { month old } \\
(\mathrm{cm})\end{array}$ \\
\hline \multirow{4}{*}{ Naungan } & 1 & 5,95 & $5,88^{\mathrm{b}}$ & $36,37^{b}$ & $43,17^{b}$ \\
\hline & 2 & $4,7,8$ & $5,27^{\mathrm{bc}}$ & $36,73^{b}$ & $39,57^{\mathrm{bc}}$ \\
\hline & 3 & $4,,, 41$ & $4,93^{\mathrm{cd}}$ & $34,45^{b}$ & $35,02^{c}$ \\
\hline & 1 & 4,88 & $5,25^{\mathrm{bc}}$ & $42,21^{\mathrm{ab}}$ & $44,11^{b}$ \\
\hline \multirow[t]{2}{*}{$\mathrm{NaCl}+\mathrm{Naungan}$} & 2 & 4,26 & $4,34^{\mathrm{d}}$ & $45,47^{\mathrm{ab}}$ & $46,23^{a b}$ \\
\hline & 3 & 4,27 & $4,42^{\mathrm{d}}$ & $37,84^{\mathrm{b}}$ & $38,06^{b c}$ \\
\hline Kontrol & 0 & 6,16 & $6,78^{a}$ & $51,06^{\mathrm{a}}$ & $57,75^{\mathrm{a}}$ \\
\hline
\end{tabular}

Keterangan : Angka yang diikuti dengan huruf yang sama pada kolom yang sama menunjukkan tidak berbeda nyata pada taraf signifikasi $5 \%$.

Remaks : Figures followed by the same letter at the same column were not significantly different at $5 \%$.

Pola perubahan diameter batang pada seluruh perlakuan sejak umur 1-7 bulan setelah pindah tanam ditunjukkan pada Gambar 2. Pola perubahan diameter batang setiap bulan cenderung lebih lambat pada seluruh perlakuan dibandingkan dengan kontrol. Pola perubahan juga cenderung mengikuti nilai diameter batang sejak bulan pertama, jadi jika pada bulan pertama diameter batang sudah menunjukkan angka yang tinggi, bulan selanjutnya pertambahannya cenderung

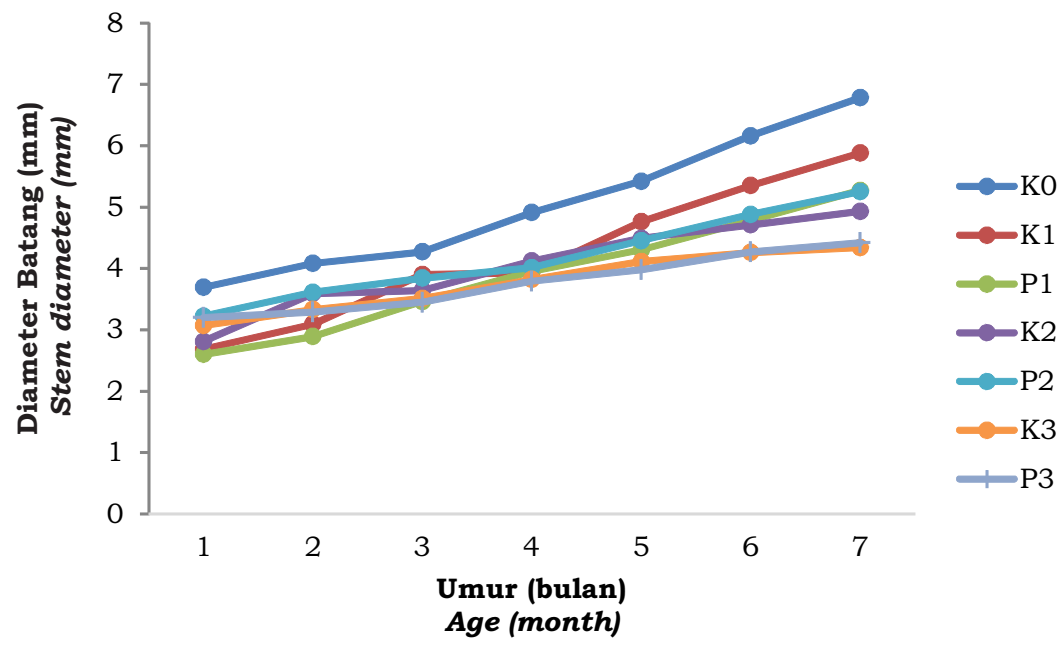

Keterangan (Remarks):

K0 : Kontrol (Control)

$\mathrm{K} 1$ : Naungan $96 \%$ selama 1 bulan (One month of $96 \%$ shading)

K2 : Naungan $96 \%$ selama 2 bulan (Two months of $96 \%$ shading)

K3 : Naungan $96 \%$ selama 3 bulan (Three months of $96 \%$ shading)

$\mathrm{P} 1$ : Penyemprotan $\mathrm{NaCl} 0,5 \%$ + naungan $96 \%$ selama 1 bulan ( $\mathrm{NaCl} 0.5 \%$ under one month of $96 \%$ shading)

P2 : Penyemprotan $\mathrm{NaCl} 0,5 \%$ + naungan $96 \%$ selama 2 bulan ( $\mathrm{NaCl} 0.5 \%$ under two months of $96 \%$ shading)

$\mathrm{P} 3$ : Penyemprotan $\mathrm{NaCl} 0,5 \%$ + naungan $96 \%$ selama 3 bulan ( $\mathrm{NaCl} 0.5 \%$ under three month of $96 \%$ shading)

Gambar 2. Pola perubahan diameter batang setiap bulan hingga bulan ketujuh setelah pindah lapang

Figure 2. Stem diameter pattern of changes in every months up to seven months after transplanting 
mengikuti. Perlakuan penyemprotan $\mathrm{NaCl}$ pada naungan yang lebih lama, cenderung menunjukkan pola pertambahan diameter yang melambat dari bulan pertama hingga bulan ketujuh, sehingga setelah bulan kelima nilainya cenderung lebih rendah dibandingkan perlakuan naungan saja.

Gambar 3 menunjukkan pola perubahan tinggi tanaman pada seluruh perlakuan sejak umur 1-7 bulan setelah pindah lapang. Tinggi tanaman seluruh perlakuan terhambat, dan nyata lebih rendah dibandingkan tanaman kontrol. Pola perubahan tinggi tanaman menunjukkan kecepatan yang hampir sama hingga lima bulan pengamatan diantara kontrol dan seluruh perlakuan. Pada bulan keenam dan ketujuh, kecepatan perubahan tinggi tanaman pada tanaman kontrol menunjukkan hasil yang nyata lebih cepat yang melampaui hasil seluruh perlakuan. Nilai tinggi tanaman di bulan pertama (setelah perlakuan) juga cenderung mempengaruhi nilai tinggi tanaman pada bulan-bulan selanjutnya. Nilai pada awal bulan yang tinggi, pada bulan-bulan selanjutnya cenderung akan tetap semakin tinggi karena kecepatan perubahannya tidak jauh berbeda.

Hasil tersebut menunjukkan bahwa hambatan pertumbuhan tetap berlanjut hingga tanaman pindah lapang. Munns dan Tester (2008) dalam Petrovic et al. (2016) menyatakan bahwa hambatan pertumbuhan akibat akumulasi garam pada awal perkembangan seedling adalah konsekuensi sebagai akibat potensial osmotik yang diinduksi oleh kadar garam. Pada tahap selanjutnya, pengaruh toksik dari ion $\mathrm{Na}^{+}$yang terakumulasi pada organ daun juga menjadi faktor yang akan menghambat pertumbuhan tanaman selanjutnya. Stres garam juga menyebabkan penurunan aktivitas lipase yang selanjutnya memicu pengurangan akumulasi pati akibat rendahnya aktivitas sintase pati pada tahap awal perkembangan. Pada tahap selanjutnya akan menghambat aktivitas fosforilase pati yang berdampak pada hambatan perkembangan seedling (Marques et al., 2013).

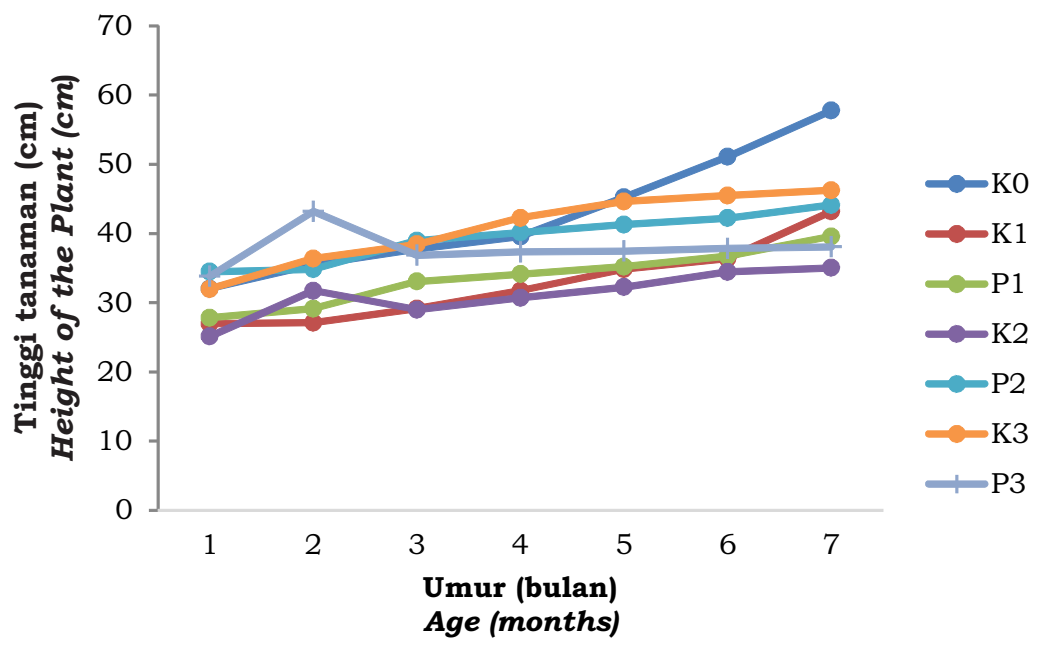

\footnotetext{
Keterangan (Remarks):

$\mathrm{KO}$ : Kontrol (Control)

$\mathrm{K} 1$ : Naungan $96 \%$ selama 1 bulan (One month of $96 \%$ shading)

K2 : Naungan $96 \%$ selama 2 bulan (Two months of $96 \%$ shading)

K3 : Naungan 96\% selama 3 bulan (Three months of $96 \%$ shading)

$\mathrm{P} 1$ : Penyemprotan $\mathrm{NaCl} 0,5 \%$ + naungan $96 \%$ selama 1 bulan (NaCl $0.5 \%$ under one months of $96 \%$ shading)

P2 : Penyemprotan $\mathrm{NaCl} \mathrm{0,5 \%} \mathrm{+} \mathrm{naungan} \mathrm{96 \%} \mathrm{selama} 2$ bulan ( $\mathrm{NaCl} 0.5 \%$ under two months of $96 \%$ shading)

P3 : Penyemprotan $\mathrm{NaCl} 0,5 \%$ + naungan $96 \%$ selama 3 bulan ( NaCl $0.5 \%$ under three months of $96 \%$ shading)
}

Gambar 3. Pola perubahan tinggi tanaman setiap bulan hingga tujuh bulan setelah pindah lapang

Figure 3. Plant height pattern of changes in every months up to seven months after transplanting 


\section{Tingkat Kematian dan Keberhasilan Okulasi}

Tabel 5 menunjukkan hasil persentase tingkat kematian seedling pasca pindah lapang, dan persentase tingkat keberhasilan okulasi pada bulan keenam dan ketujuh. Rata-rata persentase kematian mencapai $20,83 \%$. Tingkat kematian pada masa simpan satu bulan cenderung tinggi, mencapai 35\% karena pada saat tanaman dipindah ke dalam rootrainer diinkubasi di rumah kaca hanya sekitar dua jam sebelum pindah lapang. Ternyata masa inkubasi yang singkat masih menunjukkan tingkat kematian yang cukup tinggi, sehingga pada perlakuan berikutnya tanaman diinkubasi selama satu hari di rumah kaca sebelum dipindah ke lapangan.

Pada batang bawah umur 6-7 bulan dilakukan okulasi dengan tingkat keberhasilan rata-rata 40\%. Keberhasilan okulasi yang rendah diduga dipengaruhi oleh kondisi tanaman, dimana rata-rata diameter batang masih kurang dari $5 \mathrm{~mm}$. Batang bawah karet sekalipun dapat diokulasi pada usia kurang dari empat bulan dengan diameter 4-5 $\mathrm{mm}$, namun pada praktiknya tidak mudah dilakukan. Rendahnya keberhasilan okulasi, termasuk pada tanaman kontrol juga diduga akibat pengaruh iklim dimana okulasi dilakukan pada kondisi curah hujan tinggi, sekitar bulan Desember-Januari. Cuaca turut menjadi salah satu faktor yang dapat mempengaruhi tingkat keberhasilan okulasi. Kumar (2001) menyatakan bahwa beberapa faktor yang dapat mempengaruhi tingkat keberhasilan okulasi antara lain keterampilan okulator, kompatibilitas antara batang bawah-batang atas, suhu, cuaca, umur jaringan tanaman, orientasi batang atas, kelembaban tanah dan kesehatan tanaman.

Sebelum dipindah lapang, dianjurkan seedling dipindah dalam roottrainer dan diinkubasi di rumah kaca lebih lama untuk mencegah stres pemindahan dan mengurangi tingkat kematian. Perlu penelitian dan pengamatan lanjutan dengan umur okulasi setelah tujuh bulan (diameter batang $>6 \mathrm{~mm}$ ) hingga seberapa lama usia batang bawah mencapai keberhasilan okulasi yang optimal. Perlu juga diamati pertumbuhan tanaman pasca okulasi.

Tabel 5. Persentase tingkat kematian dan keberhasilan okulasi pada bulan keenam hingga ketujuh

Table 5. Achievement of budding success and death percentage level since the sixth month until the seventh month

\begin{tabular}{|c|c|c|c|c|c|c|c|c|}
\hline \multirow{4}{*}{$\begin{array}{l}\text { Hasil pengamatan } \\
\qquad(\%) \\
\text { Observation result } \\
(\%)\end{array}$} & \multicolumn{8}{|c|}{$\begin{array}{l}\text { Perlakuan } \\
\text { Treatment }\end{array}$} \\
\hline & \multirow{3}{*}{$\begin{array}{l}\text { Kontrol } \\
\text { Control }\end{array}$} & \multirow{2}{*}{\multicolumn{3}{|c|}{$\begin{array}{l}\text { Lama naungan (bulan) } \\
\text { Shading duration } \\
\text { (month) }\end{array}$}} & \multirow{2}{*}{\multicolumn{3}{|c|}{$\begin{array}{c}\mathrm{NaCl}+\text { Naungan } \\
\text { (bulan) } \\
\mathrm{NaCl+Shading} \\
\text { (month) }\end{array}$}} & \multirow{3}{*}{$\begin{array}{l}\text { Rata- } \\
\text { rata } \\
\text { Average }\end{array}$} \\
\hline & & & & & & & & \\
\hline & & 1 & 2 & 3 & 1 & 2 & 3 & \\
\hline Tingkat kematian & 0 & 35 & 15 & 20 & 25 & 15 & 15 & 20,83 \\
\hline $\begin{array}{c}\text { Keberhasilan } \\
\text { okulasi }\end{array}$ & 65 & 50 & 40 & 35 & 45 & 35 & 35 & 40,00 \\
\hline
\end{tabular}




\section{KESIMPULAN}

Perlakuan naungan 96\% dan penyemprotan $\mathrm{NaCl} 0,5 \%$ di bawah naungan nyata menghambat pertumbuhan tunas hingga 43-60\% dan diameter batang hingga 41-63\%, namun tidak menghambat pemanjangan akar pada seedling tanaman karet hingga umur tiga bulan setelah perlakuan. Hambatan pertumbuhan berlanjut hingga tujuh bulan setelah pindah lapang, mencapai $13-36 \%$ untuk diameter batang dan 20-39\% untuk tinggi tanaman. Perlakuan lama naungan satu bulan menunjukkan nilai tertinggi untuk diameter batang dan tingkat keberhasilan okulasi, yaitu $5,88 \mathrm{~mm}$ dan $50 \%$ pada umur tujuh bulan setelah pindah lapang.

\section{DAFTAR PUSTAKA}

Aminah, A., \& Syamsuwida, D. (2010). Pemberian bahan pengatur tumbuh untuk menghambat pertumbuhan semai nyamplung. Prosiding Seminar Hasil-Hasil Penelitian (p. 114-121). Bandung, Indonesia.

Bina, F., \& Bostani, A. (2017). Effect of salinity $(\mathrm{NaCl})$ stress on germination and early seedling growth of three medicinal plant species. Advancements in Life Sciences, 4(3), 77-83.

Chaves M. M., Flexas, J., \& Pinheiro, C. (2009). Photosynthesis under drought and salt stress: regulation mechanisms from whole plant to cell. Annals of Botany, 103(4), 551-560. Doi : $10.1093 / \mathrm{aob} / \operatorname{mcn} 125$

Daniel, T. W., Helms J.A., \& Baker F.S. (1997). Prinsip-prinsip silvikultur. Edisi Kedua. Yogyakarta, Indonesia : Gadjah Mada University Press.

Hawley, G.G. (1981). Condeses Chemical Dictionary 10th ed. New York, US : Nostrand Reihold. Co
Hendromono. (2001). Batas toleransi bibit Gmelina (Roxb.) dan Mahoni (King) terhadap kandungan garam air penyiraman. Buletin Penelitian Hutan. Bogor, Indonesia : Pusat Penelitian dan Pengembangan Hutan dan Konservasi Alam.

Irawan, A., \& Darwo. (2017). Respon pertumbuhan semai Shorea assamica Dyer terhadap tingkat naungan dan perlakuan bahan penghambat tumbuh. Jurnal Penelitian Kehutanan Wallacea, 6(1), 21-29. Doi : 10.18330/jwallacea.2017.vol6iss 1pp2 $1-29$

Krishnapillay, B., Tsan, F. Y., Marzalina, M., Jayanthi, N., \& Nashatul, Z. (1999). Slow growth as a method to ensurecontinuous supply of planting materials for recalcitrant seed species. Marzalina, M.; K.C Khoo; Jayanthi N.; Tsan F. Y. and B. Krishnapillay (eds). Proc. IUFRO Seed Symposium 1998 'Recalcitrant Seeds (Pp. 280-285). Kuala Lumpur, Malaysia : Forest Research Institute Malaysia

Kumar, G.N.M. (2011). Propagation of plants by grafting and budding. Washington, US : Pacific Northwest Extension Publication.

Kusumiyati., Onggo, T.M., \& Habibah, F.A. (2017). Pengaruh konsentrasi larutan garam $\mathrm{NaCl}$ terhadap pertumbuhan dan kualitas bibit lima kultivar asparagus. Jurnal Hortikultura, 27(1), 79-86. Doi : $10.21082 /$ jhort. v27n1.2017.p79-86

Marques, E.C., Freitas, P.A.F., Nara, L.M., Prisco, A.J.T., \& Gomes-Filho, E. (2013). Increased $\mathrm{Na}+$ and $\mathrm{Cl}-$ accumulation induced by $\mathrm{NaCl}$ salinity inhibits cotyledonary reserve mobilization and alters the source-sink relationship in establishing dwarf cashew seedlings. Acta Physiologia Plantarum, 35(7), 2171-2182. Doi : $10.1007 / \mathrm{s} 11738-013-1254-5$. 
Muzzayyanah, P.M. (2017). Respon empat genotipe hotong terhadap cekaman salinitas di kultur hara. (Skripsi), Fakultas Pertanian, Institut Pertanian Bogor, Indonesia.

Panjaitan, S., Wahyuningtyas., R.S., \& Ambarwati, D. (2011). Pengaruh naungan terhadap proses ekofisiologi dan pertumbuhan semai Shorea selanica (DC.) Blume di persemaian. Jurnal Penelitian Dipterokarpa, 5(2), 73-82. Doi : $10.20886 / \mathrm{jped}$. 2011.5.2.73-82

Petrovic, G., Jovicic, D., Nikolic, Z., Tamindic, G., Ignjatov, M., Milosevic, D., \& Milosevic, B. (2016). Comparative study of drought and salt stress effects on germination and seedling growth of pea. Genetika, 48(1), 373-381. Doi :10.2298/GENSR1601373P

Pey, S. C. (2012). Effect of shading on srowth of stock plants and subsequent rooting of cuttings of Aquilaria microcarpa Baill. (Thesis), Faculty of Resource Science and Technology, University Malaysia Sarawak, Malaysia.
Satjapradja, O., Setyaningsih, L., Syamsuwida D., \& Rahmat, A. (2006). Kajian penggunaan paclobutrazol terhadap pertumbuhan semai Agathis loranthifolia. Jurnal Manajemen Hutan Tropika, 12(1), 63-73.

Suminta, I. (2004). Pengaruh paclobutrazol dan NaCl terhadap pertumbuhan semai Agathis selanica Blume pada beberapa periode dan kondisi simpan. (Skripsi), Fakultas MIPA, Universitas Pakuan, Indonesia

Syamsuwida, D., Aminah, A., \& Ateng, R.H. (2010). Pemberian zat pengatur tumbuh untuk menghambat pertumbuhan semai mimba (Azadirachta indica) selama penyimpanan. 2011. Jurnal Penelitian Hutan Tanaman, 7(1), 23-31. Doi : 10.20886/jpht.2010.7.1.23-31.

Syamsuwida, D., \& Aminah, A. (2011). Teknik penyimpanan semai kayu bawang (Dysoxylum moliscimum) melalui pemberian zat penghambat tumbuh dan pengaturan naungan. Jurnal Penelitian Hutan Tanaman, 8(3), $147-153$. D o i 10.20886/jpht.2011.8.3.147-153. 